\title{
СОДЕРЖАНИЕ
}

\section{АКТУАЛЬНАЯ ПРОБЛЕМА}

Ериов В.В., Стахов А.И. Новые подходы в теории отечественного административного права и процесса

СУДЕБНАЯ ВЛАСТЬ

Клеандров М.И. Размышления на тему: может ли судьей быть робот?

\section{ЗАРУБЕЖНОЕ ПРАВО}

Терди E.C. Английская модель невозможности исполнения обязательства: история становления и особенности рецепции (на примере Индии)

\section{МЕЖДУНАРОДНОЕ ПРАВО}

Ключников А.Ю. О правотворческой роли международных судов

Магденко А.Д. Правовая природа международных стандартов,

применяемых в деятельности судебных органов Российской Федерации

\section{ОПТИМИЗАЦИЯ СУДЕБНОЙ ДЕЯТЕЛЬНОСТИ}

Чвиров В.В., Чижов М.В. Совершенствование судебной деятельности на основе информационных и коммуникационных технологий

\section{СУДЕБНАЯ СТАТИСТИКА}

Латышева Н.А. Виды судебной статистики: генезис и современные тенденции

\section{УГОЛОВНОЕ ПРАВО}

Чебуренков A.A. Некоторые проблемы дифференциации уголовной ответственности за преступления, связанные с ненасильственными сексуальными посягательствами в отношении несовершеннолетних

\section{ИМУЩЕСТВЕННЫЕ ОТНОШЕНИЯ}

Бурмакина Н.И. О реализации досудебного порядка обжалования в сфере кадастровых отношений

\section{КОНФЕРЕНЦИИ. КРУГЛЫЕ СТОЛЫ}

Сизикова Н.М., Волкова Е.И. Научно-практическая конференция «Верность Конституции» (посвящена 80-летию со дня рождения доктора юридических наук, профессора Н.В. Витрука)

Аимарина E.M., Терехова E.B. V Международная межвузовская научно-практическая конференция «Экономическое право: 


\section{CONTENT}

\section{TOPICAL ISSUE}

V.V. Ershov, A.I. Stakhov. New Approaches in Theory of National Administrative

Law and Procedure 5

\section{JUDICIAL POWER}

M.I. Kleandrov. Whether Judge Be Robot?

\section{FOREIGN LAW}

E.S. Terdi. English Model of Impossibility of Performance of Obligation:

History of Formation and Peculiarities of Reception (on example of India)

\section{INTERNATIONAL LAW}

A.Y. Klyuchnikov. On Lawmaking Role of International Courts

A.D. Magdenko. Legal Nature of International Standards Applied

in Judicial Agencies of the Russian Federation

\section{IMPROVEMENT OF JUDICIAL ACTIVITY}

V.V. Chvirov, M. V. Chizhov. Improvement of Judicial Activity on basis of Information and Communication Technologies

\section{JUDICIAL STATISTICS}

N.A. Latysheva. Judicial Statistics: Genesis and Modern Tendencies.

\section{CRIMINAL LAW}

A.A. Cheburenkov. Some Issues of Criminal Responsibility Differentiation

for Crimes Related to Non-Violent Sexual Assault against Minors

\section{PROPERTY RELATIONS}

N.I. Burmakina. On Implementation of Pre-Trial Appeal in field of Cadastral

Relations.

CONFERENCES. ROUND TABLES

N.M. Sizikova, E.I. Volkova. Overview of All-Russian Research-to-Practice

Conference "Adherence to Constitution" dedicated to 80-years Birthday

Anniversary of Prof. N.V. Vitruk, Doctor of Law.

E.M. Ashmarina, E.V. Tekhova. Economic Law: Theoretical and Practical

Aspects (5th International Interuniversity Research-to-Practice Conference)

MANUSCRIPTS SUBMISSION GUIDELINES 